\title{
What Small Countries Can Teach the World
}

\author{
JEFFREY FRANKEL*
}

In the past, various great powers have taken the stage as models of economic and social development. Examples such as Great Britain, the Soviet Union, Japan, and the United States have had their time in the spotlight that has come and gone as flaws were exposed; and other countries have learned what they did well and what they did poorly. The great powers are not the only models, however. Much can be learned from small countries which are often free to experiment with new institutions and new policies. This paper describes lessons that can be learned from such countries though no one size fits all.

Business Economics (2012) 47, 97-103.

doi: $10.1057 /$ be 2012.7

Keywords: economic development, comparative systems, economic policy, economic growth

W hy would one look to small countries when in search of good ideas for policies or institutions? It is because history shows that big countries do not have all the answers.

In the past, countries would look to the big powers for inspiration when choosing social systems, development strategies, or specific institutions. In the nineteenth century, for example, Great Britain and its industrial revolution was the model that other countries sought to emulate. Some of its innovations, such as the joint stock company and free trade, are still with us today. Others of its institutions, however, such as the gold standard, did not long survive the end of the century.

\section{Large Countries as Models in the Twentieth Century}

For some countries that gained their independence in the twentieth century, the Soviet Union became the country to emulate. Toward the end of the century, of course, the socialist model lost its appeal. It became evident to all that Russia and the other members of the Soviet bloc had failed miserably. At the same time, east Asian economies had ridden capitalism to prosperity.

Although the issue of market economics vs. socialism had been settled by 1990 , there remained competing models of capitalism. At the time, many thought the lesson of the 1980s had been that Japan's variant of capitalism was the best model and that other countries around the world should and would follow it. The model was said to include such institutions as: strategic trade policy, administrative guidance, relationship banking, life-time employment, collusive industrial groupings (keiretsu), and corporate governance that seeks to maximize the capital stock and long-term market share rather than short-term profits. ${ }^{1}$

As it turns out, there is indeed such a thing as accumulating too much capital. The Japanese model quickly lost its luster in the 1990s as the speculative bubbles of the late-1980s burst and the economy sunk into two decades of stagnation. From this, many drew the lesson that the U.S. variant of

\footnotetext{
${ }^{1}$ Vogel [1979] was ahead of his time in hailing the rise of the Japan model. Fingleton [1995] was behind his time. Johnson [1982] became a bible on Japanese administrative guidance and strategic trade policy. Frankel [1993] surveyed the special features of the financial system.
}

Based on a presentation at the NABE Annual Meeting in September 2011.

*Jeffrey Frankel is James W. Harpel Professor of Capital Formation and Growth at Harvard University's Kennedy School of Government. He directs the program in International Finance and Macroeconomics at the National Bureau of Economic Research, where he is also a member of the Business Cycle Dating Committee, which officially declares recessions. Appointed to the Council of Economic Advisers by President Clinton in 1996, he served until 1999. Before moving East, he had been professor of economics at the University of California, Berkeley. He is on advisory panels for the Federal Reserve Banks of New York and Boston, the Peterson Institute for International Economics, and the Bureau of Economic Analysis. His research interests include international finance, currencies, monetary and fiscal policy, commodities, regional blocs, and global environmental issues. He was born in San Francisco, graduated from Swarthmore College, and received his Economics Ph.D. from MIT. 
capitalism had been the best model all along. The touted institutions included American-style corporate governance: securities markets, rating agencies, accounting standards, generous compensation for CEOs (tied, for example, to options), and pursuit of profitability and share prices rather than sheer size. The United States began the 1990s with military triumph in Kuwait and ended it with the longest economic expansion in its history. Other countries should and would follow the American model.

The American model in turn lost its attractiveness in the decade of the 2000s. Its reputation for competence and integrity took some heavy blows, including the Enron-type accounting scandals of 2001, falling incomes among blue collar workers, the subprime mortgage crisis and ensuing recession, massive budget deficits, the occupation of Iraq and associated failures, and disasters in the Gulf of Mexico.

Where should countries look for a model, now? Some will respond, "China." It is undeniable that the rate of growth sustained by China over the last three decades is a miracle of history. But I find it difficult to think of many Chinese institutions that I would recommend that other countries try to copy [Williamson 2012]. Even today, China's status as the world's second largest economy owes more to the size of its population than to its GDP per capita, which has still to rise above the median level in global rankings.

We are accustomed to looking to large countries for innovations that push out the frontier of governance. But some smaller countries, and countries on the periphery, have experimented with policies and institutions that could usefully be adopted by others.

Small countries tend to be trade-dependent, and open to new ideas. Countries that are small, newly independent, remote, or emerging from a devastating war often find it easier politically to institute radical reforms than do the United States or other large, established countries. Not all the experiments will succeed. But some will. Those innovations that succeed may be worthy of emulation by others.

Let us begin with examples from countries that are small in size, but have relatively high per capita incomes.

\section{Ideas from Small Advanced Economies}

New Zealand adopted a comprehensive set of liberalization reforms, known as "Rogernomics," after Roger Douglas, a Minister of Finance, starting in 1984. Perhaps its Labor Party should even be given credit for pioneering the principle that left-of-center governments can sometimes achieve economic liberalization better than their rightof-center opponents [Nagel 1998]. New Zealand's monetary authorities pioneered inflation targeting in 1990, originally as part of a larger strategy of holding individual civil servants accountable for yearly goals. Canada in 1991 and then many other central banks over the subsequent two decades followed New Zealand in adopting inflation targeting.

Estonia led the way in simplifying its tax system by means of a successful flat tax in 1994, followed by other small countries in Central/Eastern Europe and elsewhere. ${ }^{2}$ Switzerland in 2001 put into its constitution the "debt brake." This was not a rule that the actual budget be balanced, like the impractical Stability and Growth Pact of the euro countries, but rather a rule that the structurally adjusted budget be balanced [Danniger 2002]. Germany emulated Switzerland in 2009, by putting a similar debt brake into its constitution and would like the other 16 members of the eurozone to follow suit.

Ireland recognized the importance of foreign direct investment and encouraged it by instituting a low corporate tax rate. The strategy to become the Celtic Tiger succeeded-economic growth averaged in excess of 7 percent per annum between 1995 and 2007-though the economy entered an unsustainable bubble toward the end of this period.

Canada has shown how to run a crisis-free banking system. It is not by breaking up banks that are "too big to fail" into small bits. The Canadian system is concentrated in five large banks, which hold more than 80 percent of bank assets, but the authorities have never had to bail them out. Public policy in Ottawa does not seek artificially to increase the extent of owner-occupied housing by encouraging loans that the households may not be able to repay: mortgage interest is not tax deductible, a 20 percent down payment is standard (unless the borrower takes out insurance), and mortgages are "full recourse" loans (defaulting does not let the borrower off the hook). The result is that Canada achieves the same level of home

\footnotetext{
${ }^{2}$ Including Latvia, Lithuania, and Slovakia [Saavedra 2007].
} 
ownership as the United States, but with far less leverage, fewer defaults, and no systemic crises [Perry 2010].

Sweden in 1992 showed how to move aggressively to rescue a banking system in crisis while yet taking steps so that the taxpayer eventually gets all or most of his money back [Dougherty 2008; Larsen and Giles 2009]. ${ }^{3}$ This example helped inspire the U.S. government's redesign of the Troubled Asset Relief Program in early 2009.

More broadly, the Scandinavian countries, after deciding that they had swung too far in the high-spending socialist direction in the 1970s, made some adjustments in the 1990s [Aslund 2010; Becker, 2007; Borg 2010]. The "Nordic model" has by now shown that it is possible to combine a high level of social protection, social services, and corporatist labor relations with market economics, fiscal responsibility, and free trade. According to Anders Aslund [2010], Denmark was the pioneer in the 1980s, in which case we should call this the Scandinavian model, followed in the 1990s by Sweden under the prime ministership of Carl Bildt. High female participation in the labor force is one ingredient in the formula. Sweden's comprehensive school voucher system may be another.

Norway has the highest ranking in the global Human Development Index. Some will say, "That is easy, Norway has oil." But many countries with oil or other natural resources squander the proceeds. (More on this below.) Norway enacted laws to ensure that its oil revenue was saved in sovereign wealth funds.

The modern Scandinavians are distinguished by their recognition that they should have tax revenues sufficient to match what they want their governments to spend. Still, Sweden's conservative government was able to cut taxes on the working poor in 2010, reasoning that their incentives are adversely affected by high total marginal tax rates (whereas America's supply-siders seem to think that this logic applies only to the rich). The U.K. Prime Minister, David Cameron, reportedly would like to import this idea to Britain [Sumner 2010].

In the 1990s, the Netherlands decided that its high level of taxation, labor market regulation,

\footnotetext{
${ }^{3}$ The Swedish example is viewed in contrast to the Japanese approach during the 1990 s, which was to drag out as long as possible a recognition and resolution of their banks' difficulties, thereby greatly increasing the cost to the nation in the end.
}

and social protection was keeping employment artificially low. It experimented with reforms to make labor markets more flexible, making part-time work easier in particular. The result was that the Netherlands became the top job-creator in Europe. ${ }^{4}$ Crucially, workers are apparently choosing part-time work voluntarily-because it suits their life style, rather than as part of some artificially imposed "work-sharing" scheme [Bosch and others 2009]. The "Dutch model" provided some of the inspiration for Germany's successful labor market reforms in the following decade.

\section{Ideas from Newly Industrializing Economies}

Particularly intriguing are the innovations that come from developing countries, or at least countries that were "developing" when they started. Some of these countries have been so successful that they are no longer classified as developing.

Singapore long ago achieved rich country status and by 2011 ranked fourth highest in the world in income per capita (PPP adjusted) - ahead of the United States. It accomplished this miracle with a unique development strategy. Among its many innovations were a paternalistic approach to savings and use of the price mechanism to defeat urban traffic congestion, subsequently emulated by London [Goh 2002; Santos 2007].

Famously, Korea in 1957 was at about the same level of income as the newly independent Ghana, and development economists thought that the latter country had much the better prospects. Today Korean income ranks twenty-fifth in the world, just ahead of the EU average! Part of the explanation of Korea's industrialization miracle was its commitment to education. The country ranks first in the world in test scores of its 15 -year-olds in reading, and second in math after Finland. ${ }^{5}$

Costa Rica in Central America and Mauritius in Africa each pulled ahead of its peers some time ago. Among many other decisions that worked out

\footnotetext{
${ }^{4}$ About half of Dutch job creation since the mid-1980s has been part-time jobs taken by women aged 25-49. A 1997 EU survey reported that 72 percent of part-time workers in the Netherlands did not want a full-time job instead [Garibaldi and Mauro 2000]

${ }^{5}$ The U.S., by contrast, ranks twenty-fifth in math, out of 38 countries studied, behind Hungary [Organization for Economic Cooperation and Development 2011, pp 87, 89].
} 
well for them, both countries have foregone a standing army. The result in both cases has been histories with no coups and financial savings that can be used for education, investment, and other productive purposes [Frankel 2012a]. ${ }^{6}$

Mexico in the 1990s, largely thanks to the leadership of President Ernesto Zedillo, adopted nonpartisan federal electoral institutions that subsequently in 2000 allowed the opposition party to take power for the first time, and in 2006 Mexico was able to resolve successfully a disputed election [Henríquez 2006]. ${ }^{7}$

In 1998, Mexico also pioneered the idea of conditional cash transfers (CCT) by launching the program that was originally called PROGRESA and subsequently changed to OPORTUNIDADES. ${ }^{8}$ CCT programs have subsequently been emulated by Brazil's Bolsa Familia and many other developing countries. They have even inspired reforms in New York City. The Mexican innovation was two revolutions in one: (1) the specific idea of making poverty transfers contingent on child school attendance and (2) the methodological idea of conducting controlled experiments to find out what policies work or do not work in developing countries, which has fed into the exciting Randomized Control Trials movement in development economics [Rawlings and Rubio 2005; Fernald and others 2008].

\section{Ideas from Commodity-exporting Countries}

Countries that with natural resource wealth have not performed better than those without, a phenomenon known as the Natural Resource Curse. ${ }^{9}$

\footnotetext{
${ }^{6}$ Military spending in Mauritius is only about U.S.\$6 per capita, equal to 0.45 percent of GDP or 4 percent of spending on education and health. [Brautigam 1997, p.153] One might argue that a remote island country has little need of armed forces, but Mauritius has in fact suffered the loss of territory to external military force. The United States and United Kingdom took the Chagos Islands in order to build the base of Diego Garcia, without the permission of either the islanders or Mauritius. Of course, Mauritius was hardly in a position to resist, with or without an army. But small size has not stopped other countries from futile military endeavors.

${ }^{7}$ In contrast, it turned out in November 2000 that the United States had no mechanism to resolve such disputes, other than the preferences of a few critically situated political appointees.

${ }^{8} \mathrm{CCT}$ s make anti-poverty payments contingent upon the receivers' actions, such as enrollment of children in school, getting regular medical check-ups, and other self-help actions.

${ }^{9}$ Frankel [2012c] surveys the Natural Resource Curse and some possible remedies. One institutional reinforcement
}

One aspect of the curse historically has been a tendency for exporters of oil, energy and agricultural products no to over-spend in a boom rather than to save. This tendency is part of a more general historical pattern of procyclical or destabilizing fiscal policy among developing countries. Remarkably, however, roughly one third of them have managed to overcome this weakness since 2000 , and to run countercyclical spending policies instead. ${ }^{10}$ The star performer in this reversal is Chile. The story has possible not just for commodity-exporters but for all countries.

A variety of innovations has helped Chile to outperform its South American neighbors. ${ }^{11}$ Chile's fiscal institutions - structural budget balance with the parameters estimated by independent panels of experts - insure a countercyclical budget. They are among the mechanisms that are particularly worthy of emulation by other commodity exporting countries.

Chile ran large surpluses during the copper boom of 2003-08, and subsequently was able to ease its fiscal policy substantially in the recession of 2009. This achievement was not solely the result of wise policymakers choosing the right policies. They were helped by an institutional framework that had been put into place in 2000, and that can provide a useful model for others [Frankel 2012b]. Chile's fiscal institutions consist essentially of three rules.

First, each government must set a budget target. Second, as in Switzerland, the target is phrased in structural terms: Deficits are allowed only to the extent that output falls short of trend, in a recession or if the price of copper is below its trend. The target for the structural budget surplus was set at zero in 2008 under President Michelle Bachelet, which implied a substantial actual surplus because the oil price was high and the economy was booming.

Third, the determination of what is structural and what is cyclical is made by two panels of inde-

against corruption is the Extractive Industries Transparency Initiative. In 2009 Azerbaijan became the first country designated as EITI-complaint, and Liberia became the first country in Africa.

${ }^{10}$ Frankel, Vegh and Vulentin (2011)

${ }^{11}$ The structural budget regime is of course but one of many innovative reforms that Chile has adopted over the last few decades. Many of them have been successful and potentially worthy of emulation [Edwards and Edwards 1991 and 2000; Corbo and Fischer 1994; Velasco 1994; and FfrenchDavis 2010]. 
pendent experts, who project 10 -year trends, outside the political process. The result is that Chile avoids the pattern of 32 other governments, where forecasts in booms are biased toward over-optimism. This helps explain why it was able to run surpluses in the 2003-07 boom. The United States and Europe failed to do so in part because their fiscal authorities made systematically over-optimistic forecasts during this period of expansion.

Mexico appears again on our list of innovators for its success in hedging of oil export proceeds on option markets. Producers who sell their minerals on international spot markets are exposed to the risk that the U.S. dollar price rises or falls. The producer can hedge the risk ahead of time by selling that quantity on the forward or futures market or options. Hedging provides efficient sharing of risk and automatic adjustment to changes in world prices. Using futures markets to hedge has one serious drawback from a bureaucratic or political point of view. If a government ministry hedges on the futures market, the minister receives no credit for having saved the country from disaster when the world price falls but is excoriated for having sold out the national patrimony when the price rises. Better, then, is the hedging strategy employed by Mexico: it uses options to eliminate only the risk of a fall in the price of oil. In this way it retains the upside risk while reducing the downside risk [Duclaud and García 2011].

The proceeds of commodity exports should be used to establish sovereign wealth funds that are transparent and professionally managed, in order to assure that future generations share the bounty while investing in assets that earn a higher rate of return than the paltry return on U.S. Treasury bills, where most central bank reserves are held. The model that has been touted most widely is the Norwegian Pension Fund (formerly called the Norwegian State Petroleum Fund). But it may not in fact be the best model for most commodity exporters to emulate. One wants a sovereign wealth fund to be placed out of the reach of political influence and invested solely along financial lines. This is not the practice with Norway's fund, where politicians can dictate constraints based on social goals [Holmøy 2010].

A better model for most commodity exporters is Botswana's "Pula Fund," built on earnings from the sale of diamonds. The fund, invested entirely in securities denominated in other currencies, serves both as a sinking fund to offset the depletion of diamonds and as a buffer to smooth economic fluctuations.
Management of the Pula Fund is delegated to independent professionals with instructions to pursue only the financial interest of the people of Botswana, undistorted by any political goals.

\section{Silver Bullets?}

There is a good reason why the phrases "silver bullet" or "panacea." only appear in English when preceded by the word "no."

In highlighting some very specific institutions that could be usefully applied elsewhere, I do not mean to suggest that they can be effortlessly translated from one national context to another. Many countries would not be able to handle the still-large government sectors of the Scandinavian countries, for example, without corruption or mismanagement. Land redistribution worked well in Japan, Korea, and Taiwan after the collapse of the Japanese colonial empire in 1945; but in most other contexts such interference with property rights would inflict lasting damage. ${ }^{12}$ It is unlikely that the U.S. political system could successfully implement the sort of flat taxes that have worked in Eastern Europe. When an American politician proposes a flat tax it is invariably accompanied by snake-oil promises of impossibly low rates. When he or she proposes to open up the tax code to simplify it, it often comes out more complicated.

I also do not mean to suggest that the examples of good innovations that I have identified are entirely responsible for the success of the economies in which they were made. Countries such as Chile, New Zealand, and Singapore have undertaken many reforms not mentioned here. Nor do a few good policies necessarily determine outcomes. Ireland and Estonia were among those worst hit by the global financial crisis of 2008, in part because they had given up monetary independence. As the example of Mexico shows, a country can have a number of brilliant innovations and still suffer from stagnant growth for other reasons - in Mexico's case the crippling effects of the relocation of the drug trade from Colombia and a flood of guns from the United States. ${ }^{13}$

But a country does not have to be large to serve as a model for others. Small countries are often more free to experiment with new policies and new institutions. The results provide some useful lessons.

\footnotetext{
${ }^{12}$ Some examples are cited by Kuznets [1988].

${ }^{13}$ Among other factors, Hanson (2010).
} 


\section{REFERENCES}

Aslund, Anders. 2010. The New Scandinavian Model, Peterson Institute for International Economics, http://www.piie .com $/$ blogs $/$ ? $\mathrm{p}=1813$.

Becker, Uwe. 2007. "The Scandinavian Model: Still an Example for Europe?" International Politics and Society, 4: 41-57.

Borg, Anders. 2010. Getting Fiscal Consolidation Right: Lessons from Sweden, Speech at London School of Economics (January 14), http://www.sweden.gov.se/sb/ d/9698/a/138026.

Bosch, Nicole, Bas van der Klaauw, and Jan van Ours. 2009. "Female Part-time Work in the Netherlands," Vox (September 5), http://voxeu.org/index.php?q= node /3946.

Brautigam, Deborah. 1997. "The "Mauritius Miracle": Democracy, Institutions and Economic Policy," in State, Conflict, and Democracy in Africa, edited by Richard Joseph. Lynee Riener, 137-62.

Corbo, Vittorio, and Stanley Fischer. 1994. "Lessons from the Chilean Stabilization and Recovery," in The Chilean Economy: Policy Lessons and Challenges, edited by Barry Bosworth, Rudiger Dornbusch and Raúl Labán. Brookings Institution, 29-67.

Danniger, Stephan. 2002. “A New Rule: The "Swiss Debt Brake", IMF Working Paper 02/18. International Monetary Fund, January.

Dougherty, Carter. 2008. "Stopping a Financial Crisis, the Swedish Way," New York Times (September 23).

Duclaud, Javier, and Gerardo García. 2011. Mexico's Oil Price Hedging Program. International Monetary Fund.

Edwards, Sebastián, and Alejandra Cox Edwards. 1991. Monetarism and Liberalization: The Chilean Experiment. University of Chicago Press.

Edwards, Sebastián, and Alejandra Cox Edwards. 2000. "Economic Reforms and Labour Markets: Policy Issues and Lessons from Chile." Economic Policy, 15(30): 181-229.

Fernald, Lia, Paul Gertler, and Lynnette Neufeld. 2008. "Role of Cash in Conditional Cash Transfer Programmes for Child Health, Growth, and Development: An Analysis of Mexico's Oportunidades." Lancet, 371(March): 828-37.

Ffrench-Davis, Ricardo. 2010. Economic Reforms in Chile: From Dictatorship to Democracy, 2nd edn. Palgrave Macmillan.

Fingleton, Eamonn. 1995. Blindside: Why Japan Is Still on Track to Overtake the U.S. by the Year 2000. Houghton Mifflin.

Frankel, Jeffrey. 1993. "The Evolving Japanese Financial System, and the Cost of Capital," Chapter 9, in Restructuring Japan's Financial Markets, edited by Ingo Walter and Takato Hiraki. Irwin Press and New York University, 235-85.
Frankel, Jeffrey. 2011. "Over-optimism in Forecasts by Official Budget Agencies and Its Implications." Oxford Review of Economic Policy, 27(4) and NBER WP 17239.

Frankel, Jeffrey, Carlos Végh, and Guillermo Vuletin. 2011. "On Graduation from Procyclicality," NBER WP 17619, November.

Frankel, Jeffrey. 2012a. "Mauritius: African Success Story," forthcoming, 2012, in African Successes, edited by Sebastian Edwards, Simon Johnson and David Weil. HKS RWP 10-036, University of Chicago Pres.

Frankel, Jeffrey. 2012b. "A Solution to Fiscal Procyclicality: The Structural Budget Institutions Pioneered by Chile," forthcoming in Fiscal Policy and Macroeconomic Performance, edited by Luis Felipe Céspedes and Jordi Galí. Series on Central Banking, Analysis, and Economic Policies (Central Bank of Chile). CBC WP No. 604, NBER WP No. 16945, April 2011.

Frankel, Jeffrey. 2012c. "Natural Resource Curse: A Survey of Causes and Some Remedies," forthcoming, in Commodity Price Volatility and Inclusive Growth in Low-income Countries, edited by Rabah Arezki and Zhu Min. International Monetary Fund.

Garibaldi, Pietro, and Paolo Mauro. 2000. "Job Creation: Why Some Countries Do Better," Economic Issues No. 20 (International Monetary Fund), April.

Goh, M. 2002. "Congestion Management and Electronic Road Pricing in Singapore." Journal of Transport Geography, 10(1): 29-38.

Hanson, Gordon. 2010. "Why Isn't Mexico Rich.” Journal of Economic Literature, 48(4): 987-1004.

Henríquez, Jesús Orozco. 2006. "The Mexican System of Electoral Conflict Resolution in Comparative Perspective." Taiwan Journal of Democracy, 2(1): 51-60.

Holmøy, Erling. 2010. "Mineral Rents and Social Policy: The Case of the Norwegian Government Oil Fund," in Financing Social Policy: Mobilizing Resources for Social Development, edited by Katja Hujo and Shea McClanahan. UNRISD/Palgrave Macmillan.

Johnson, Chalmers. 1982. MITI and the Japanese Miracle. Stanford University Press.

Larsen, Peter Thal, and Chris Giles. 2009. "Self-assembly Solution," Financial Times (March 18), http://www .ft.com/intl/cms/s/0/d8e57fc4-135f-11de-a170-0000779f d2ac.html.

Kuznets, Paul W. 1988. "An East Asian Model of Economic Development: Japan, Taiwan, and South Korea." Economic Development and Cultural Change, 36(3).

Nagel, Jack. 1998. "Social Choice in a Pluralitarian Democracy: The Politics of Market Liberalization in New Zealand." British Journal of Political Science, 28(2): 223-67. 
Organization for Economic Cooperation and Development, 2011. Education at a Glance: Highlights. 13 September, OECD.

Perry, Mark. 2010. "Due North: Canada's Marvelous Mortgage and Banking System," The American (February 26).

Rawlings, Laura, and Gloria Rubio. 2005. "Evaluating the Impact of Conditional Cash Transfer Programs." The World Bank Research Observer, 20(1), http://www .crin.org/docs/Evaluatingpercent20thepercent20Imapact percent20ofpercent20Cashpercent20Transferpercent 20 Programs.pdf.

Santos, Georgina. 2007. "Congestion Pricing: An Idea that Makes Sense," Vox (July 25), http://www.voxeu.org/ index.php?q $=$ node $/ 410$.

Saavedra, Pablo. 2007. "Flat Income Tax Reforms," Chapter 8, in Fiscal Policy and Economic Growth in
Eastern Europe and Central Asia, edited by Cheryl Gray, Tracey Lane and Aristomene Varoudakis. World Bank, http://siteresources.worldbank.org/INTECA/Resources/ 257896-1182288383968/FiscalPolicy\&EconomicGrowth inECA Ch8.pdf.

Sumner, Scott. 2010. "What Do We Mean by "Economic Reform"?" The Money Illusion (September 27), http:// www.themoneyillusion.com/?p=7112.

Velasco, Andrés. 1994. "The State and Economic Policy: Chile 1952-92," in The Chilean Economy: Policy Lessons and Challenges, edited by Barry Bosworth, Rudiger Dornbusch and Raúl Labán. Brookings Institution, 379-410.

Vogel, Ezra. 1979. Japan as Number One: Lessons for America. Harvard University Press.

Williamson, John. 2012. "Is the 'Beijing Consensus' Now Dominant?" Asia Policy, 13(January): 1-18. 